\title{
FOUNDATION OF THE NEW RAILWAY BRIDGE OVER THE NOSICKÁ DAM ON THE RIVER VÁH
}

\begin{abstract}
MAROŠ ZAŤKO
Zakládání staveb, a.s., organizačná zložka Bratislava, Košická 56, 82108 Bratislava, Slovakia

correspondence: zatko@zakladani.cz

Abstract.

The new railway bridge over the Nosická dam is a part of the complex modernization of the railway corridor from Púchov to Žilina. Our company participated on the project using a wide variety of special foundation techniques on artificial islands for piers P6, P5, P4 and P3 and the pillar foundations. We applied the many years of experience gained by our company through working on projects involving water. Bored piles, as well as vibrated sheet piles, welding and assemblage work have all been carried out from a floating pontoon platform and also there was jet grouting applied to stabilize embankments. At the same time we provided active assistance with temporary floating bridges and platforms for the kind of transfer on water required by our client.
\end{abstract}

KEYWORDS: Foundation in water, jet grouting, piles, sheet piles.

\section{INTRODUCTION}

As part of the first phase of the modernization of the Púchov - Žilina railway line for speeds of up to 160 $\mathrm{km} / \mathrm{h}$ on the interstation section Púchov - Považská Bystrica, our company has been carrying out special foundation work on structure SO 44.33.21.1 on a new railway bridge over the Nosická dam going back to autumn 2016 - see Fig. 1. The investor is the company Železnice Slovenskej republiky, a.s, Bratislava, the main contractor is the association Združenie Nimnica, while its leading member Doprastav a.s. is our client for the special foundation of the bridge. The general designer is the company REMING CONSULT, a.s. and the responsible designer of the bridge foundation is the company LKM Consult s.r.o.

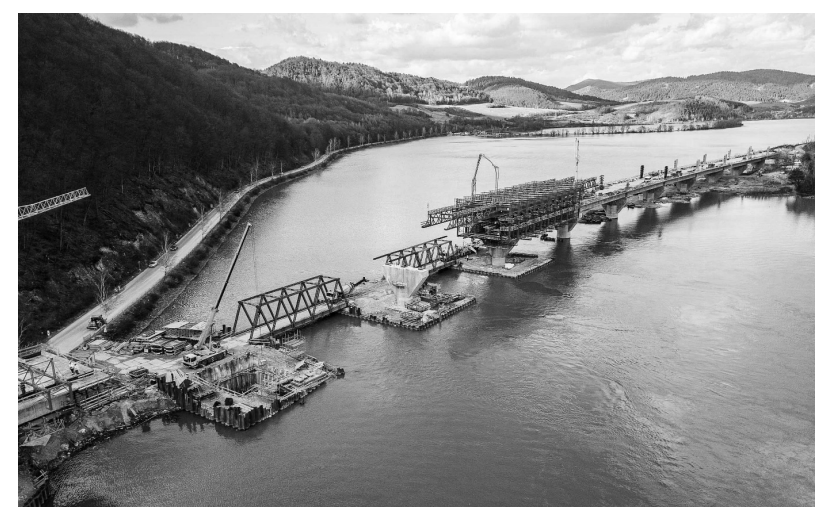

Figure 1. New railway bridge over the Nosicka Dam during construction

\section{INFORMATION CONCERNING THE BRIDGE}

The bridge carries a railway line designed for a speed of $160 \mathrm{~km} / \mathrm{h}$ from the Diel tunnel across the Nimnická road II / 507 Nimnica - Považská Bystrica and further obliquely above the Nosická dam water reservoir. At the end, it connects to SO 44.33.21.2 - the bridge under the double-track railway line, which transfers to the road III / 5171 from Milochov to Považská Bystrica. After its completion, the bridge will allow river navigation through two navigable corridors in fields 3 and 4 . The proposed load-bearing structure of a 12 -pole straight bridge of two-chamber crosssection made of prestressed concrete with a typical span of $51.5 \mathrm{~m}$ fits well to the nature of the bridged obstacle and the bridge length. The company Zakládání staveb a.s. carried out pile drilling from the water surface on pillars P3, P4, P5 and from the terrain on $\mathrm{P} 6$, sheet piles vibrating and assembly work on the construction of sheet sumps for pillars P3, P4, P5 and a peninsula for pillars P6, P7, and finally jet grouting on all 4 foundations [1]. Due to our many years of experience and involvement with the technological equipment of the company, the contract also included filling embankment in sumps, assembly work on the water surface and various other handling and auxiliary work that required the assistance of pontoon platforms and tugs.

\section{Geology}

As part of the detailed IGP, no drilled probes were performed in the deeper riverbed of the river Váh. The level of the Mesozoic sandstone and claystone formations and the possible boulder zone was determined by simply using geophysical methods and sheet driving experiments, by which the possible driving depth was verified. Typical geology at the site of drilled piles begins with a layer of alluvial muddy sediments with the character of clay sand and a thickness of $4 \mathrm{~m}$. Under them was gravel with a mixture of fine-grained soil G3 / G-F to a depth of $7 \mathrm{~m}$ below the bottom. After 
that gravels G3-G-F to G5GC with clay filling occurs to a depth of $12 \mathrm{~m}$. From $12 \mathrm{~m}$ to $14.5 \mathrm{~m}$ there begins the subsoil formed of weathered sandstones, which from $14.5 \mathrm{~m}$ deeper changed into healthy sandstones of medium to high strength R3-R2.

\section{THE WORKING TASKS}

\subsection{Preparatory WORK}

As part of the preparatory work for operating on water, also embarkation of equipment and materials, there was realized a dock edge between pillars P11 and P12 made of vibrated sheet piles reinforced by a circumferential stiffening beam. At this landing place, the Kobelco 550 crawler crane first replaced individual parts of the pontoon from the surface to water, where they were, one by one, joined by connecting rods into an assembly configuration according to the required scheme. At the turn of February and March 2017, a technological test of high-frequency sheet piles vibrating took place. The machinery set including wheel crane LTM40, hydraulic aggregate, vibrating hammer and auxiliary container, boarded a pontoon platform pushed by the tug boat VeronikaII and set off to geodetically marked places for forthcoming works. The sheet vibrating was performed using one calibrated sheet profile with a marked scale in meter units. This test was applied on places of future pillars P3 - P8. Experiments for pillars P9 to P12 were performed from the embankment. The objective of these attempts was to verify the actual levels of solid subsoil, and where sheet vibrating would be deemed ineffective. The result was that this geological layer was generally higher than had been assumed, which led to an acceptable reduction in the length of the sheet piles.

\subsection{Timeline OF WORK}

The work started in May 2016 with pile drilling from the water surface on the P5 foundation and continued towards the other riverbank (direction Nimnica) at P4 and P3. After 3 months of work on the water the drilling rig disembarked and work continued on the meanwhile completed peninsula P6, P7 where the drilling was realized from the terrain. For all islands there was designed double rectangular barrier sheeting walls around the bridge pillar base foot. Sheet piles vibrating began on the $\mathrm{P} 6, \mathrm{P} 7$ peninsula. After completion pits for islands $\mathrm{P} 5$ and $\mathrm{P} 4$ was vibrated including welding and framing work. The realization of the island P3 walls could start only after partial withdrawal of $\mathrm{P} 6 \mathrm{P} 7$ sheeting piles to maintain the water flow profile of the dam. All vibrating was realized from the pontoon on the water surface. The embankment body of the P6 P7 peninsula was built from the shore by gradually pouring the material into the water into the space bordered by the sheet pile walls. The P3 peninsula was similarly built from the other bank. Temporary pontoon bridges were used to fill the P4 and P5 islands with material. Embedding a heavy stabilizing rocky embankment on the outer sheeting wall perimeter was performed by a floating platform on which heavy duty trucks laden with rocks were shipped across the water. After the completion of the piles on P6, jet grouting was carried out, followed by $\mathrm{P} 5$ and $\mathrm{P} 4$ islands, always after the realization of an embankment of sheet. After that the complete construction of the P6 and P7 bridge pillars could begin sheet pile extraction and this material was subsequently used in realization of the island P3. After this completion and embankment filling, jet grouting also followed. One of the main boundary conditions for successful conduct of the construction work was the level regime at Nosice dam. The minimum operating level of the dam is $274.60 \mathrm{~m}$ above sea level. $\mathrm{m}$. and maximum $279.60 \mathrm{~m}$ above sea level whereas for the static design of temporary structures in the riverbed there was considered a minimum design level $276.00 \mathrm{~m}$ above sea level. The normal regime of construction work was such that without restriction it was possible to perform in the interval above a min. design level $276.00 \mathrm{~m}$ above sea level. and below a max. operating level $279.60 \mathrm{~m}$ above sea level. Mainly for assembly and welding work on the sheeting wall barriers the water level had to be kept to a value up to $277.6 \mathrm{~m} \mathrm{n}$. $\mathrm{m}$.

\subsection{Pile DRILLING}

Pilot groups under the pillars P5, P4 and P3 were realized in a profile of $900 \mathrm{~mm}$. A drilling rig stood on a pontoon platform of suitable configuration which had been anchored by steel ropes to the sheet piles vibrated in advance in the river flow - see Fig.2. For the needs of drilling works, the pontoon platform was modified by adding a welded steel frame used to guide the drill casing, to hang it and jam during the drilling process. On the pontoon there was placed two maintenance half-containers, a power generator, concrete pipes, along with funnel and drilling tools. The pontoon assembly was first guided geodetically from the shore and pushed by tugboat to the approximate place of drilling. During these maneuvers against the water current, the pontoon was mostly fixed by two ropes to the anchoring sheet piles to make it easier to handle in the water flow. For a more precise positioning of pontoons there were used four hand winches with steel ropes on each corner of the pontoon platform. When the position of the platform was approximately correct, the stabilizing legs were dropped down to the bottom of the riverbed to minimize horizontal movements due to drilling, current, torque and at the same time to prevent vertical movements that would be dangerous to the stability of the pontoon. The correct position of the drill casing was geodetically checked from the shore by aiming to the center of the casing.

The piles on P3 were $11 \mathrm{~m}$ long, on P4 $12 \mathrm{~m}$ on P6 $16 \mathrm{~m}$ and on $\mathrm{P} 5$, at the deepest point of the flow, it was 


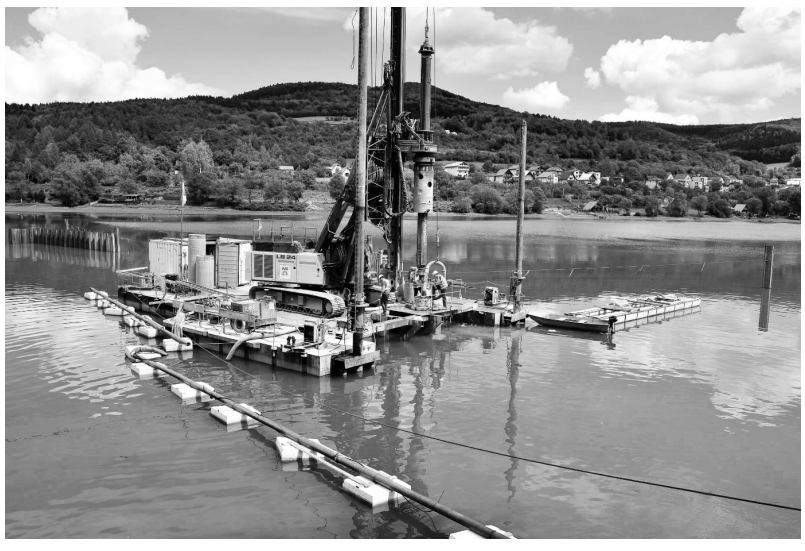

Figure 2. Realization of piles from pontoon

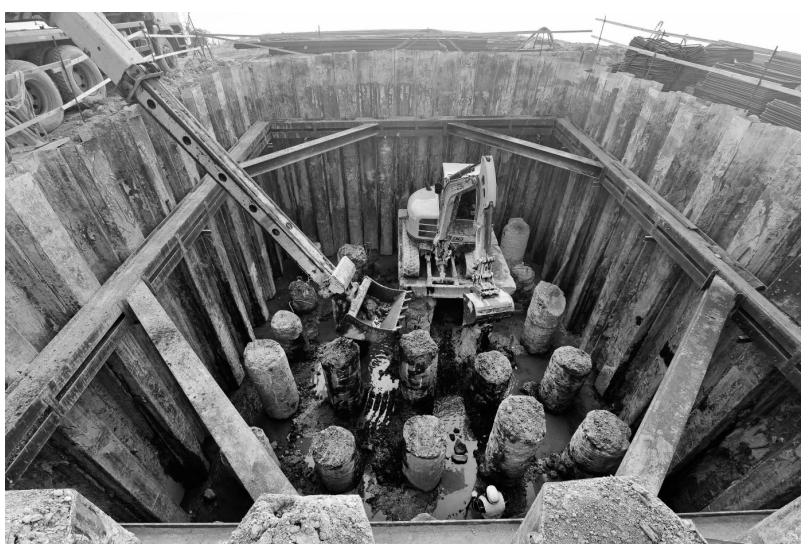

Figure 3. Exposed piles in a sheet pile sump

$16.5 \mathrm{~m}$. The requirement of the project was to adjust the length of the pile according to the specific geology and other matters, and by this the reinforcement cage was to be lengthened or shortened by a selected method. According to the control plan there was to be geological supervision present during the drilling of each pile, checking the match of the geological profile with the project and the quality of borehole bottom, which according to the project should be obliged to a min. $1 \mathrm{~m}$ into the bedrock and thoroughly cleaned with a flat bottom drilling pot. For concreting, a floating pipe with a diameter of $150 \mathrm{~mm}$ was prepared composed of $6 \mathrm{~m}$ long pieces. In the middle of each pipe was attached a polystyrene block so as to keep it above the water when the pipe is full of concrete. By connecting the parts there was created a pipeline of a length up to $150 \mathrm{~m}$ with which it was possible to transport the concrete mixture across the water to the drilled pile hole. For that purpose, the pump MECBO Pulsar 6.80 was used. To ensure the full body of pile and the quality of its head in the muddy deposits, the piles were concreted much more than usual - see Fig. 3 Pilot work on the P6 pillar was carried out from the terrain of the artificial peninsula P6 P7 which was built in the meantime.

\subsection{SheEt PILES VIBRATING AND ASSEMbly WORK}

Along with the drilling rig pontoon platform, another one was designed for the ramming work, made of 5 fragments, so the dimensions of the platform were $15 \mathrm{~m} \times 9 \mathrm{~m}$. A LIEBHERR LTM30 wheeled crane was placed on the platform, which was clamped and anchored to the deck with chains. Behind it was placed a service semi-container and a hydraulic unit driving the ICE1423 vibro-rammer. A PS50 military auxiliary pontoon was used to supply the main pontoon with sheet piles, rods, steel profiles and other necessary material. A smaller part of a pontoon of this type was used as a working platform for welders needed to carry out a large number of welding and locksmith work around the sheet piles structures. The workers were transported across the river by a motorboat, which also served as a means to inspect the quality of work. The vibrating began on the $\mathrm{P} 6 \mathrm{P} 7$ peninsula so that drilling and vibrating pontoon formations would not interfere with the water flow.

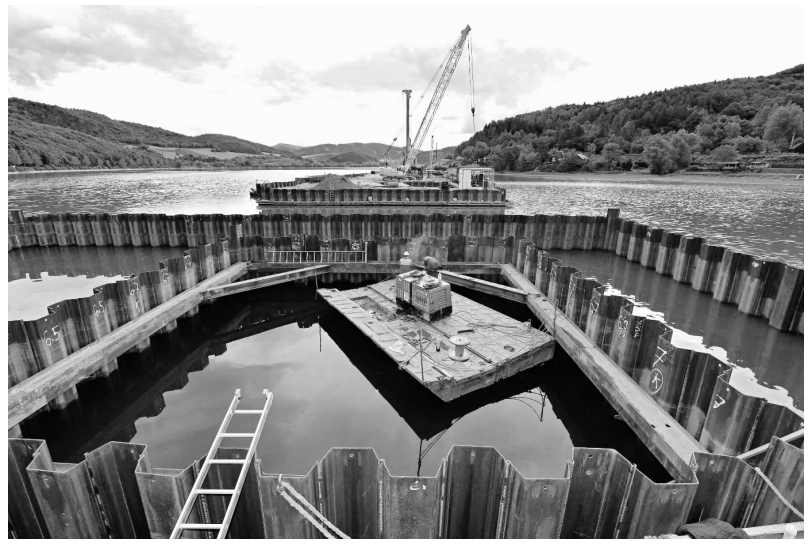

Figure 4. Mounting the spacer frame in the sump

This started by vibrating two parallel walls at a distance of $7.7 \mathrm{~m}$ from each other from the tip of the embankment towards the water flow stream. Gradually, beams of 2xIPE270 were installed on the outer perimeter of the walls, and in the projected places, the walls were tied through GEWI bars $50 \mathrm{~mm}$ in diameter. Geodetically guided sheet piles were laid out, according to which the correct position of the rammed sheet piles was then maintained. During the double rectangular barrier sheeting walls, so called sumps, the inner sump was first vibrated and closed. On selected sheet piles, consoles were welded in an exact height position to fit the lower of the three spacer frames. On P6, these frames had dimensions of $12 \mathrm{~m} \times 11 \mathrm{~m}$ and consisted around the perimeter of 2xIPE400 profiles reinforced in the corners with two HEB300 diagonals. First, the lower frame was welded and assembled above the water level, then lowered by a crane below the surface where it was to be landed on the mentioned consoles on the sheet piles. This operation was assisted by a diver, whose task was to check the position of the mounted frame and to install 
boundary wedges between the IPE profiles and the sheet piles to activate the frame. Due to the higher level of mud sediments at the bottom, the lower frame could not be lowered to the projected depth but was fixed and wedged $120 \mathrm{~cm}$ higher. Subsequently, the upper spacer frame was assembled above the surface in its projected position - see Fig. 4 The assembly of the middle spacer frame was carried out in the later phase of construction on the terrain of the already built island. On finishing the sheet pile walls and closing the outer walls, the assembly of stiffening beams and GEWI tension rods continued. After the completion of part of the walls, the filling of the wall-bordered space began, which gradually created a new peninsula. At the same time, a heavy stone throw was made on the outside perimeter of the sheet pile walls by placing half meter large boulders next to the wall. Poured material in front of the sump pushed the thin muddy sediments which sometimes had to be removed so as not to degrade the material of the embankment body. This effect was most visible when the filling reached the end of the peninsula. While carrying out the filling of the peninsula, visible deformations in the shape of the walls were detected and the sheet piles of the outer perimeter wall slightly bulged outwards. As a countermeasure, there was implemented an additional external embankment of the peninsula with a heavy stone dump in problem areas in order to ensure the stability of the foot of the sheet piles. During this phase of realization, the embankment pushed against the walls of the inner pit when it was not yet loaded from all 4 side evenly, which then began to tilt it and gradually deform it. This situation led to some reinforcing measures and project revision.

\subsection{Jet GROUTING}

Based on monitoring of sheeting walls deformation after the filling of embankments, the designer was ordered to additionally reinforce the $\mathrm{P} 6 \mathrm{P} 7$ peninsula by adding transverse rods and extending the jet grouting project - see Fig. 5 .

The use of jet grouting technology had 4 goals:

- creation of a watertight sealing around the outer perimeter of the inner sheet pile walls in order to prevent water leakage through the wall

- sealing and strengthening the bottom of the pit with pillars of J.G. between the foundation piles and thus creating a hydraulically resistant block with a thickness of $4 m-5 m$

- remediation of embankments in order to reduce uneven deformations of the embankment body, eliminate the risk of tilting of drilling rigs, and to minimize the overall settlement of the embankment around the foundations of the temporary bridges and around the crane platforms. At the same time, J.G. was used to increase the overall rigidity and resistance of the island body in the event of an extreme flood.
- creation of a jet grouting block, which was designed in the vicinity of all micropile foundations of the temporary bridges on $\mathrm{P} 3, \mathrm{P} 4, \mathrm{P} 5$ and $\mathrm{P} 6 \mathrm{P} 7$

The mobilization of jet grouting technology was planned after the completion of sumps filling and finishing of piles on the $\mathrm{P} 6 \mathrm{P} 7$ peninsula. As the first stage there was improving the embankment body. In the previous period, during its construction inside the sheet pile sumps, there were significant deformations of sheet piles and local declines in the embankment terrain, and especially at the end of the peninsula, which thus required an improvement project. The resulting design included more ribs from J.G., a fullarea block of J.G. under the base of the temporary bridge and additional stiffening beams and rods in the transverse direction of the peninsula P6P7. Grooves were dug in the projected places into which these reinforcing elements were inserted, and through the inserted strings they were connected to the sheet pile walls. After the implementation of these measures, jet grouting began. First, ribs from directed MONO jet grouting to a depth of $6 \mathrm{~m}$ were realized, then a block of pillars by the M2 method 900 and $1200 \mathrm{~mm}$ in diameter to a depth of $6 \mathrm{~m}$ below the temporary bridge foundations, also sealing of the perimeter sheet pile walls from directed MONO jet grouting to a depth of $14 \mathrm{~m}$ and finally a block of J.G. columns in the bottom of the inner sump between piles with a thickness of $5.2 \mathrm{~m}$ was completed. On P5, P4 and P3, the inner sumps were not filled with backfill but with water, so special steel frames with massive beams were mounted above the sump.

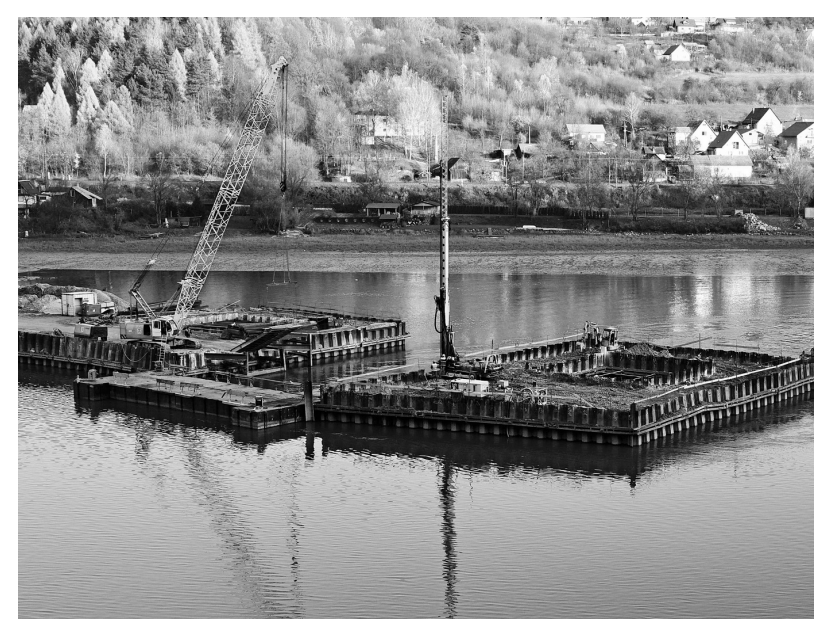

FiguRE 5. Implementation of jet grouting

Six-meter-long VL604 sheet piles were placed on them, which created a removable work platform for the drilling rig. At the point of drilling, single sheet pile was removed and the drill instrument was lowered through the water column to the bottom. The total length of the borehole was $15 \mathrm{~m}$. The designed pillars with a diameter of $1400 \mathrm{~mm}$ and $900 \mathrm{~mm}$ were grouted in ascending order by the M1 method or two-phase air M2 method. Thus, blocks with a thickness of $5.2 \mathrm{~m}$ 
and a minimum strength of $2 \mathrm{MPa}$ were realized on the individual pillars. Sealing walls on the outside of the inner sump were also made while drilling from steel platforms. Here, a two-row MONO directed jet ascending grouting with oscillation was used with borehole spacings of $1.5 \mathrm{~m}(0.7 \mathrm{~m}$ alternately and $0.4 \mathrm{~m}$ between the rows), while the grouting length was $11 \mathrm{~m}-15 \mathrm{~m}$. The leached material remained at the bottom of the pit and was extracted during the excavation to the base foot level. The work process and especially the technological breaks were very strict in order to avoid deformations. As a foundation for a temporary bridge M60 for connection of islands P4, P5 with peninsula $\mathrm{P} 6 \mathrm{P} 7$, there were realized two groups of three micropiles TR 114 / $12.5 \mathrm{~mm}$ length $12 \mathrm{~m}$ with injected root length $9 \mathrm{~m}$ under each support.

\subsection{WORKING ON WATER}

In addition to pile drilling, vibrating the sheet piles and assembly work, it was also necessary to deploy pontoon platforms of various configurations for less usual tasks during the transfer of material for external and internal embankments of sheet piles sumps. A pontoon platform $15 \mathrm{~m} \times 18 \mathrm{~m}$ was used to place a heavy stone throw around the islands of P5 and P4 see Fig.6 It was handled by a pair of tugs Veronika II. For embarkation, a port edge with ramp was made on the edge of the $\mathrm{P} 6 \mathrm{P} 7$ peninsula.

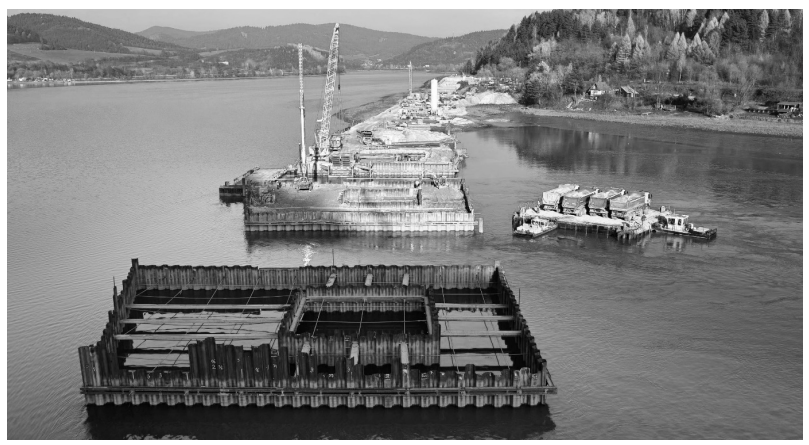

Figure 6. A heavy stone backfilling

It was fixed by joint, and possible to lift and lower by crane. There could have been 4 trucks on board with a total weight of 160 tons. As it was a relatively complex and risky activity, instruction was prepared by an authorized expert in the field, from whom the method of performing the entire operation was prescribed. The vehicles gradually reversed onto the pontoon and were secured in a precisely determined position in the order of $1,3,2$ and 4 so that the pontoon was loaded evenly. Before and after boarding each vehicle, the ramp was raised and lowered as the pontoon was moved along the port edge and the ramp was placed against the intended vehicle position. This was so that the cars did not need to maneuver on the platform but were only moving in a straight line. After securing them by inserting wedges under the wheels, the pontoon was pushed to a sheet pile wall, where it was hooked on by a rope and the cars gradually reversed to the edge of the pontoon and dumped the load in to the water just next to the sheet piles. After the implementation of these external embankments, the pontoon set was dismantled and rebuilt into a pontoon bridge between the artificial islands. Over these floating bridges the cars transferred and poured the material into the pit $\mathrm{P} 5$ or P4. Pontoon assemblies were needed for other work, such as moving material, laying cables to the bottom of the dam, or cutting sheet piles with the assistance of a diver. The bridge contractor used pontoons for excavation of the underwater embankment after demounting the artificial islands and returning the bottom of the dam to the original state. A pontoon was also used to dismantle some parts of the sliding concreting structure after finishing the bridge skeleton in the middle of the span above the water, a task which would otherwise be difficult to carry out.

\section{Conclusion}

Work on the bridge should be completed in autumn 2020. The construction of bridges over the dams brings a number of unusual problems but offers opportunityfor interesting solutions especially in the field of special foundation, as the construction of the pillars no longer differs much from a similar bridge in terrestrial conditions. By the end $12,200 \mathrm{~m}^{2}$ of sheet piles had been vibrated and 185 tons of steel had been seized to the structures and $2200 \mathrm{~m}$ GEWI rods had been installed. There were also completed $1500 \mathrm{~m}$ of piles and $8400 \mathrm{~m}$ of jet grouting. Almost 36,000 cubic meters of embankment had been incorporated into artificial islands P3 - P5.

\section{REFERENCES}

[1] M. Zatko, J. Šperger, Modernization of the Railway Line Púchov - Žilina, Foundation of a Railway Bridge over the Nosice Dam on the River Váh, Journal Fundation, Záklání staveb a.s., vol. XXXI, n.4/2019, ISSN 1212 - 1711, Prague 2019. 